\title{
Planning for Sustainable Tourism. Case Study: Kampung of Cookies, Surabaya, Indonesia
}

\author{
Mimin A. YUSUF ${ }^{* 1},{ }^{2}$, Rahardian ARI $^{1}$, Rika KISNARINI ${ }^{1}$, Dewi SEPTANTI ${ }^{1}$, Happy R. SANTOSA ${ }^{1}$ \\ ${ }^{*}$ Corresponding author \\ ${ }^{1}$ Sepuluh Nopember Institute of Technology, Surabaya, East Java, INDONESIA \\ 2 Islamic University Darul Ulum Lamongan, East Java, INDONESIA
}

E-mail:miminaminahyusuf@gmail.com

DOI: 10.24193/JSSP.2019.1.05

https://doi.org/10.24193/JSSP.2019.1.05

K e y w o r d s: sustainable tourism, tourist Kampung, Home Based Enterprise (HBE), Indonesia

\begin{abstract}
A B S T R A C T
'Kampung' is high density, lower middle class and informal settlement in Indonesia that is located in the city. It is usually inhabited by low income people. One of the kampungs that have the potential to be developed as a tourist kampung is Kampung of Cookies, in the city of Surabaya. This kampung has a unique tourism potential that is the development of home based enterprises (HBEs) in the form of traditional cookies production and has excellent community participation. However, the development process is not yet optimally. It still lacks facilities and specific government intervention to become a tourism destination and attraction. The purpose of this research is to formulate the development concept so as Kampung of Cookies should become a tourism destination. We proposed the sustainable tourism approach being expected that the concept obtained could comply with the principles of sustainability. The first method used in this research is descriptive qualitative performed by observation and interview. Further, data obtained in the field were analyzed based on aspects of sustainable tourism. The concept of area development for sustainable tourism was then formulated. The result of this research is a develobment concent probosal for the Kampung Rungkut Lor Surabava that is based on sustainable tourism.
\end{abstract}

\section{INTRODUCTION}

According to the national development plan in Indonesia, one of the leading sectors that should be developed in the period 2015-2019 is the tourism sector (National Development Planning Agency, 2014). This is supported by the Surabaya government one of which flagship programs is tourism development. According to Surabaya City Profile 2016, although it does not have an amazing natural landscape, Surabaya develops another model of nature tourism making effort to realize the Green Open Space, the rejuvenation of the park and the development of tourist kampung (Department of Communication and Informatics of Surabaya, 2016). Kampung can be an interesting attraction because it is an urban settlement in Indonesia and has its own uniqueness (Funo et al., 2002).

In addition to the national development program in the field of people's welfare (among income groups) there is special attention paid to micro, small and medium enterprises (National Development Planning Agency, 2014). Surabaya responded to the issue by increasing the volume of HBEs (Home Based Enterprises) and improving the quality of cooperatives (City Development Planning Board of Surabaya, 2015). The effort is undertaken in order to increase the interest of prospective workers to the entrepreneurship, to facilitate cooperation network among small entrepreneurs, to enhance competence and 
competitiveness of cooperatives and micro business actors, to support the development of creative business, to empower economic-based groups that has not been oriented to the creation of competitiveness effort. So far, cooperatives have been less oriented towards increasing competitiveness, and have not yet been attracted to community participation and towards inclusion into cooperatives. Kampung of Cookies Rungkut Lor proves to be suitable to respond to tourism and HBEs issues. This kampung has a unique tourist attraction namely the development of HBEs that produce traditional cookies. In addition, Kampung of Cookies has been known throughout Surabaya, although it is still not so popular either nationally or internationally. Some television stations have been covering it and many students both within the country and abroad paid visits to this kampong. Unfortunately, the existing service facilities are very limited so the development cannot be optimal. In order to become a tourist kampung, the intervention of the local city government is needed.

The sustainable tourism approach is the right approach to develop the tourism potential in this Kampung of Cookies. This is supported by the Ministry of Trade in Indonesia that has set a number of policies at the national level to support the implementation of sustainable tourism development (Ministry of Tourism, 2009). The core of these two policies promotes the principles of sustainable tourism development, such as energy efficiency, biodiversity conservation, and decent work that pay attention to environmental aspects and also the importance of optimizing the function of sustainable tourism. Sustainable tourism is one the supporting factors of urban economy and for sustainable development (United Nation, 2016). Sustainable development itself aims to improve the quality of human life in all aspects including physical, cultural, religious, and spiritual without disregarding existing resources (Setyaningsih et al., 2014).

\section{THEORY AND METHODOLOGY}

\subsection{Literature review}

Kampung is a typical indigenous urban settlement mostly inhabited by lower-middle-class people (Silas, et. al., 2013: o8). Tourist kampung is a form of integration consisting of attractions, accommodation and supporting facilities presented in a community life structure united in prevailing ways and traditions (Nuryanti, 1993).

According to Inskeep (1991), Gunn (1988), Mill and Morrison (1985) the most important factors found in tourism are tourist destinations, attractions and services. Meanwhile, according to Yoeti (1996) Suwena (2010) aspects of tourism include tourist attractions, accommodation, transportation, infrastructure, and supporting facilities. The success of a tourist kampung includes the target of tourists, locations, tourist facilities, architecture, and image (Isabella, M. 2010). Agoes (2015) stated that the criteria that tourist kampung should comply with are: 1) tourism should utilize facilities and infrastructure provided by the local communities; 2) it should involve local communities; 3) it should implement the development of rural tourism products and 4) it should offer a variety of distinctive attractions.

Indonesia is now applying the concept of sustainable tourism. Based on the United Nations World Tourism Organization recommendations environmental, economic, and social-culture are the most significant aspects in the development of sustainable tourism (UNWTO, 2005). According to Kurniawati (2013) sustainable tourism consists of several aspects such as community participation, stakeholder involvement, local ownership, sustainable resource use, accommodating community goals, bringing capacity, monitoring and evaluation, accountability, training and promotion.

All tourism aspects mentioned above will be taken as the context of this study but will be grouped as follows: tourist attractions: image, community objectives, and capacity; tourist destinations: location, target tourist, transportation, nearby facilities, and accommodation; environment: service, facilities, infrastructure, resource use, and architecture; economics: local ownership, promotion, and training; and social culture: participation, involvement, and monitoring / evaluation.

\subsection{Method}

The method used in this research was descriptive qualitative performed by observation and interview. Observation technique was applied by using documentation. The characteristics observed were about the physical condition provided by the kampung (existing area, house condition, drainage, road, garbage, greening, parking, traffic jam, and public facilities).

Interviews were performed in relation to the members of the local community and the initiator of the Kampung. Questions were elaborated and grouped into the social, cultural, and economic categories. The questions for the local community were different from the ones addressed to the initiator. For the initiator, the questions were related to the history of kampung of cookies, community participation, community organization, government assistance and management. The details consisted by the questions addressed to the locals, are mentioned below:

Social and cultural: the daily, weekly, monthly and annual activity; level of participation (involvement); sense of community; social facilities (healthy facilities, mosque, market etc.). 
Economic: income per month; promoting the product; business legality; branding and packaging.

Interviews were also conducted in order to determine the desire of the community for the development of the kampung. This was very important because this Kampung was created through a bottomup development.

After all data were obtained, the next step was to create a design based on the results obtained by analysing the variables that include the physical, social, cultural, and economic conditions. The analysis was done by linking to the existing aspects of the sustainable tourism approach. Thus, the concept of sustainable tourist kampung development could be elaborated.

\subsection{Current situation and history of the area under study}

Surabaya has had a long history of improving its kampungs. This kampung improvement effort began in 1924 and has lasted until now. There were various types of kampung improvement programs including KV (Verbetering Kampung), W.R Supratman, World Bank, UNEP, UNICEF, P2BPK, KIP-K, PLPBK, P2KP, CoBuild, RSDK, NUSSP, PNP Mandiri, and superior kampung (timeline on Fig. 1).

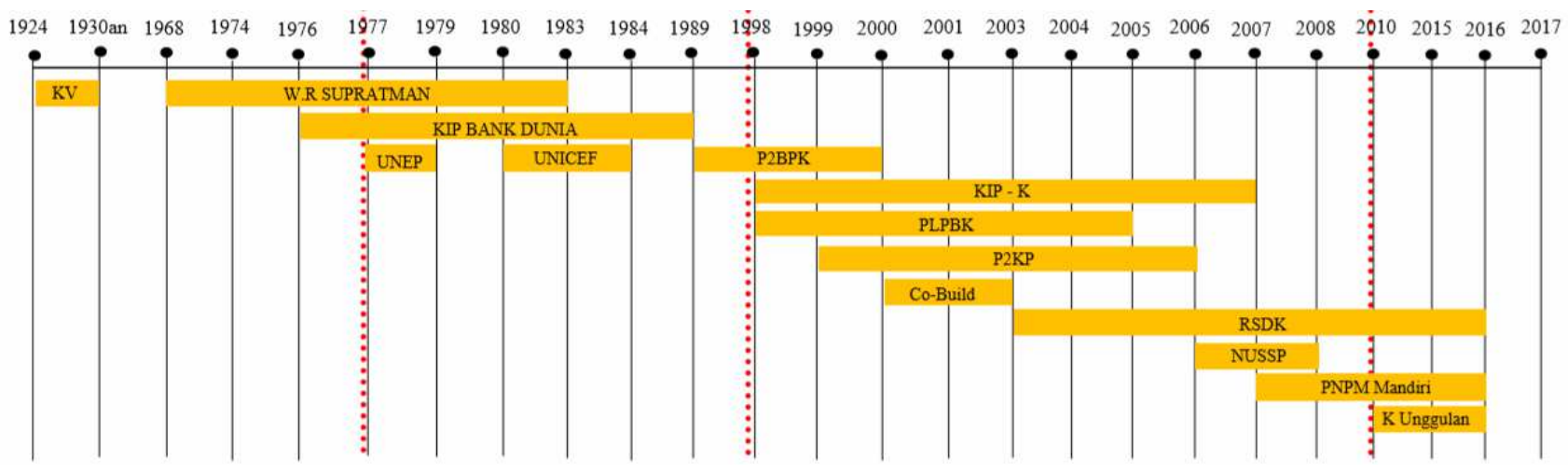

Fig 1. The period of kampung improvement program in Surabaya (Dianingrum, 2017).

Before the existence of superior kampung, most of the kampung improvement programs were only based on physical improvement as eradicated slum effort. But in 2016, through an advanced kampung program the government included economic elements in the enhancement of their kampung (Dianingrum, 2017).

Government policy of Superior kampung was 'one kampung one product', so every kampung in Surabaya has its own uniqueness. For example, as mentioned in this paper, there were Kampung of Cookies in Rungkut, Kampung of Handicraft in Kedung Sari, Kampung of Shoes in Tambak Osowilangun, etc.

Surabaya government implemented a bottomup system for improving its kampong, so the primary stakeholder was the community. The government assisted in actions related to capital, marketing, training, packaging, promotion (local, national and global), stakeholder development, and business legality.

Finally, the kampung improvement program carried out by Surabaya was aimed for tourism, thus elaborating the kampung tourism program (Department of Communication and Informatics of Surabaya, 2016). This research aimed to propose a development pattern for the kampung of cookies to become a tourist kampung.

Kampung of Cookies Surabaya is located in Jl. Rungkut Lor Gang II, Kali Rungkut, Rungkut Surabaya (Fig. 4).

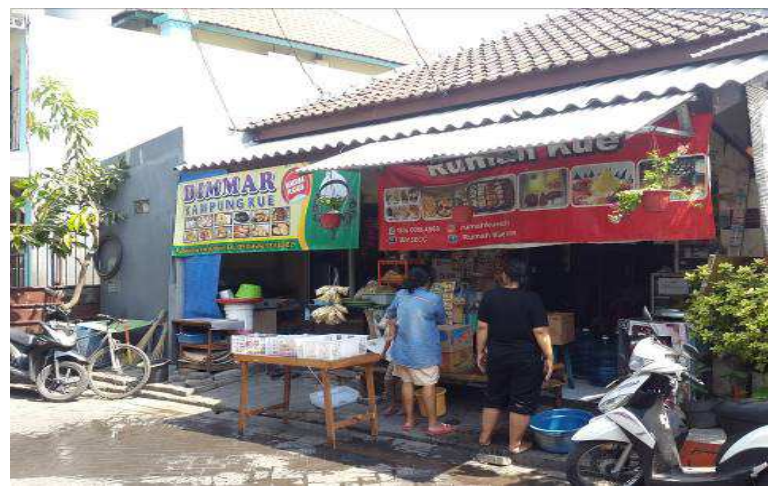

Fig. 2. Cookies shop.

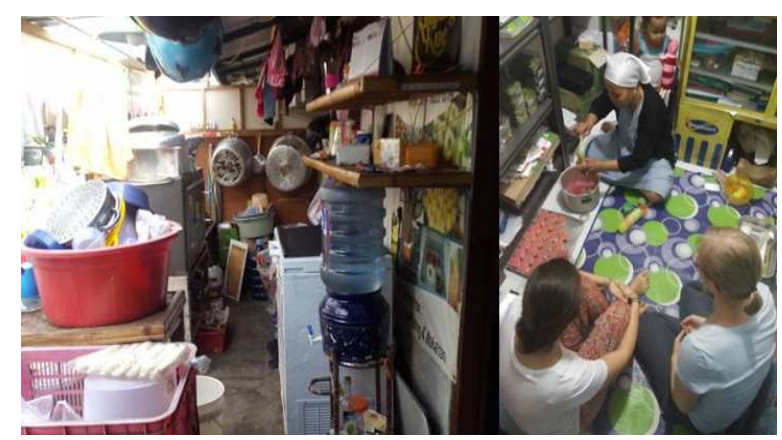

Fig. 3. Production room.

This kampung is bordered by: Rungkut Lor street, alley 1 (to the North); Rungkut Asri Utara street 1 (to the East); Rungkut Lor street, alley 5 (to the South); Rungkut Road (to the West). 
Kampung of Cookies was inaugurated in 2008 by Surabaya government although this kampung initiated its business in 2000. Business development started during the monetary crisis that caused many employees to lose their jobs, some of whom were individuals from this local community. So the community has got an idea to create their own business. The idea of creating this kampung was spearheaded by an initiator in community at the time.

Currently, Kampung of Cookies is not yet developed for tourism purposes. No tourism facilities are offered besides cookies shops (see Fig. 2) and production spaces (for learning how to make cookies). (see Fig. 3).

\section{RESULTS AND DISCUSSION}

The analysis of the development of Surabaya Kampung of Cookies was performed on five components, namely: tourist attractions, tourist destinations, environment, economy, and social culture.

\subsection{Tourist attractions}

According to Hidayat et al. (2018) tourist attraction represents an attraction that is owned somewhere so as to attract people to travel. Currently, the Kampung of Cookies has its own charm to be developed into a tourist kampung. It is the only Kampung of Cookies in Surabaya that is located in the middle of the city. Every year, the number of visitors increased including cookies middlemen, students both from the country and abroad, lecturers and others. This increased number of visitors is determined by the numerous reports made by mass media on this subject. This is in the context of labour demonstrations at the factory made by activists and due to the influence of the initiator of this kampung, thus reporters being interested about the state and evolution of this kampung. Considering the high potential level, the concept of tourist attraction that can be developed around this kampung involves the demonstration of cookies making, cookies festival, cookies display, and cookies cartoon photo-spot.

Cookies festival is an annual program in this cookie tourism kampung. The festival is intended to promote traditional cookies. It lasts several days, and there are several contests and demonstrations of how to make the cookies. This festival is held along the main alley of the kampung. The cookies demonstration program is conducted every month. It is intended for all communities either inside or outside kampung, students and others who are interested in learning how to make cookies. The demonstrated cookies are not only the long-known cake, but also the innovative cookies that have been created by the cake-making mothers of this kampung. To be sustainable, tourist attractions must be developed in accordance with the trend and interest of tourists, but it should not eliminate the unique character of the Kampung of Cookies.

To accommodate the above attractions, some supporting facilities such as cookies showroom, mural wall, and signboards are needed. Below, we provide a description for each facility.

\subsubsection{Showroom, cafe and information centre}

Café-Showroom is used as a central place for souvenirs and baking demonstrations. As land is very limited, the showroom is placed in the east of the kampung and facing directly to Rungkut Asri Utara street 1 (Fig. 4).

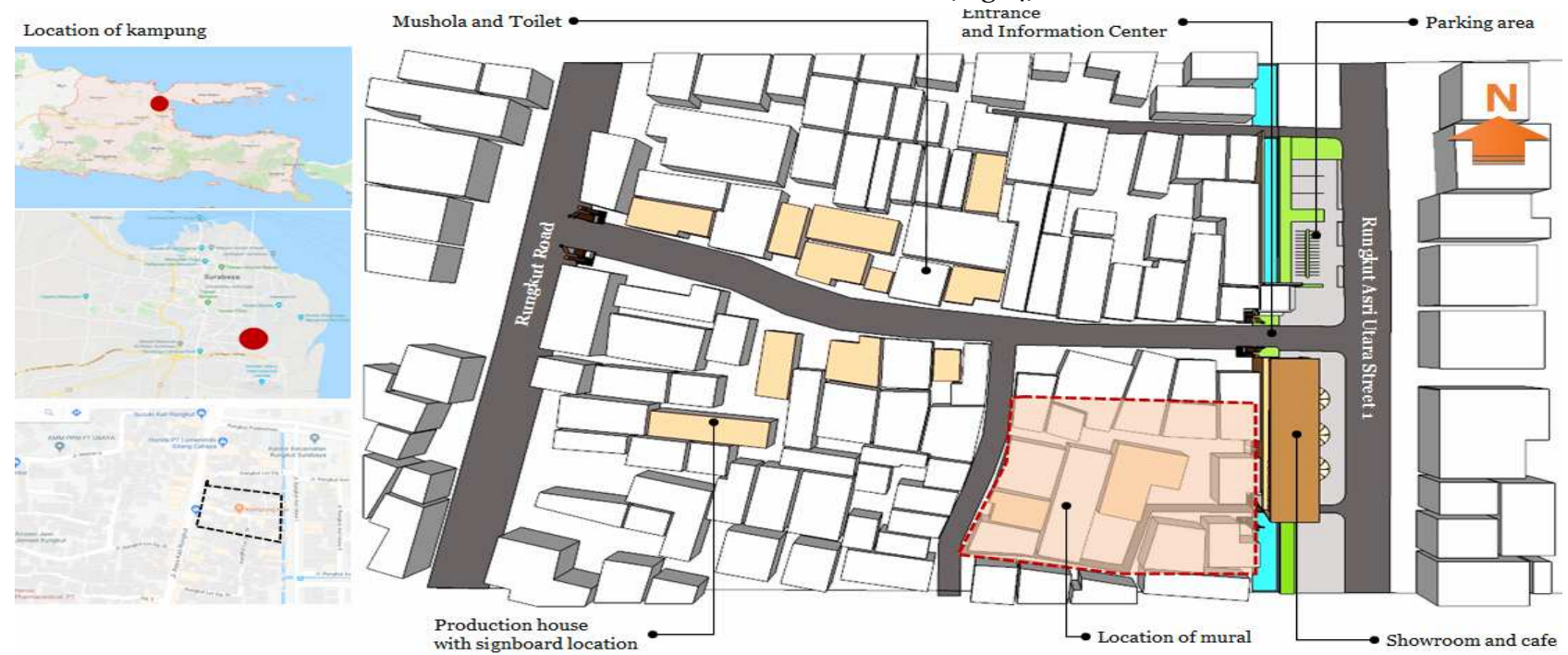

Fig. 4. Location and Layout Plan of Tourist kampung.

The concept of this cafe is integrated with cookies showroom so that visitors can buy cookies as well as sit back at the cafe. The cafe is designed using the semi-outdoor concept (Fig. 5). 


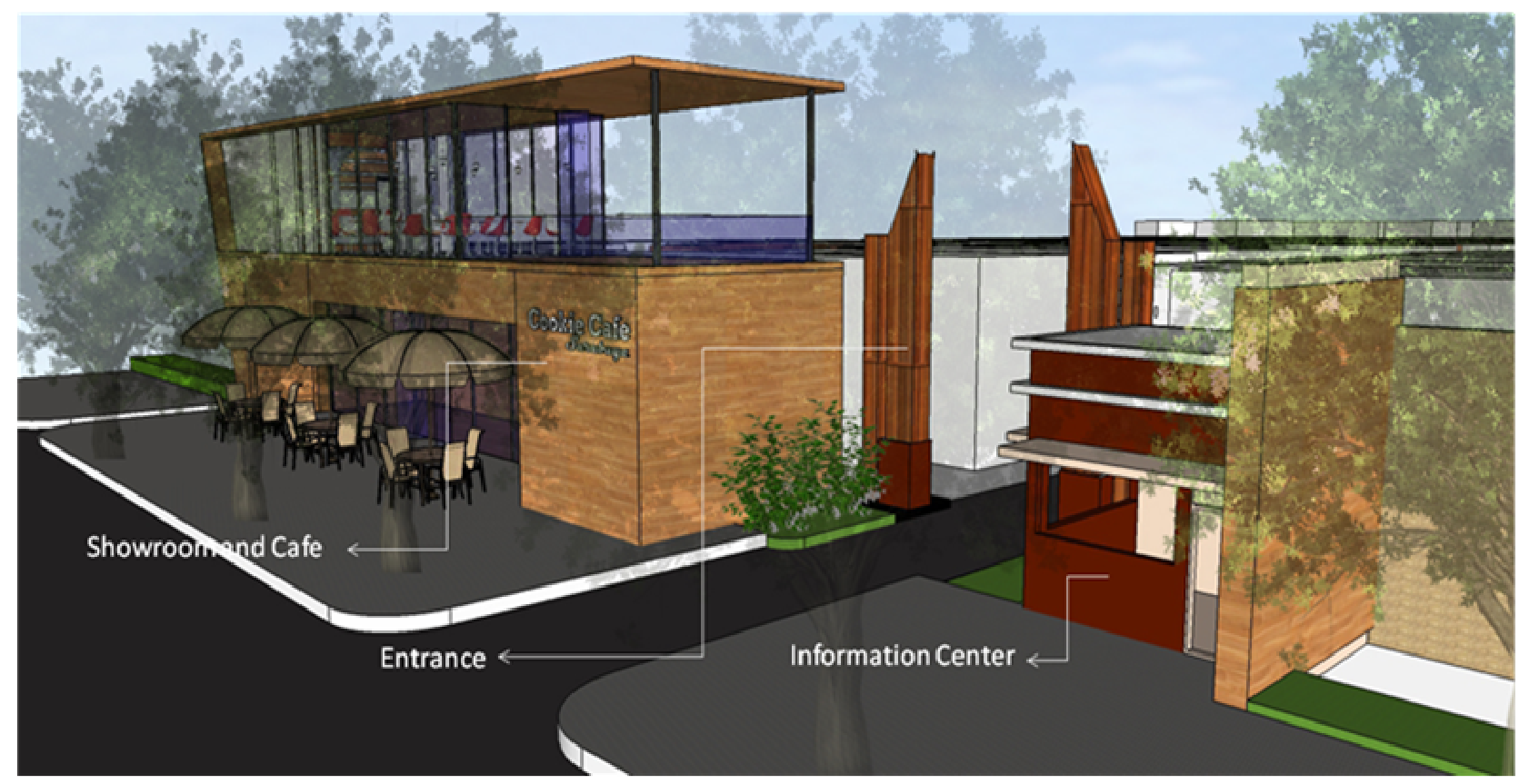

Fig. 5. Proposal for showroom, cafe and information.

\subsubsection{Wall and street mural}

Mural is one of the artistic elements that can be used as a tourist attraction. Alike the kampung of Dago, the attraction of this kampung is the mural, be them on the walls of houses, alleys, or fortresses (Hidayat et al., 2018).

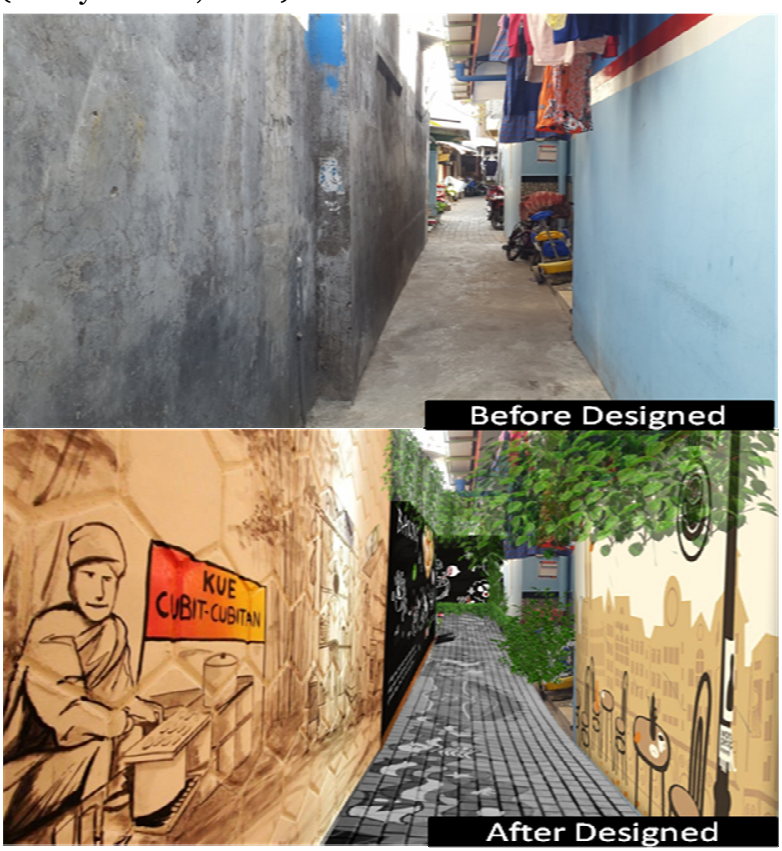

Fig. 6. Wall Mural Proposal (source: mural illustration by Morbielegance.com and Dining.grivy.com).

Mural has its own appeal in tourism development (Aditya, 2015). Since nowadays there are facilities of social media, public interest in photography becomes very high (Mulyadi, 2014). This interest starts from paying attention to a specific thing or activity, taking pictures for documenting it (Zakaria and Supriharjo, 2014). So the mural has a huge potential to attract tourists.

The location of the mural wall is in the southern area (see Fig. 4). This is because there are many clean and wide walls (Fig. 6 before being designed).

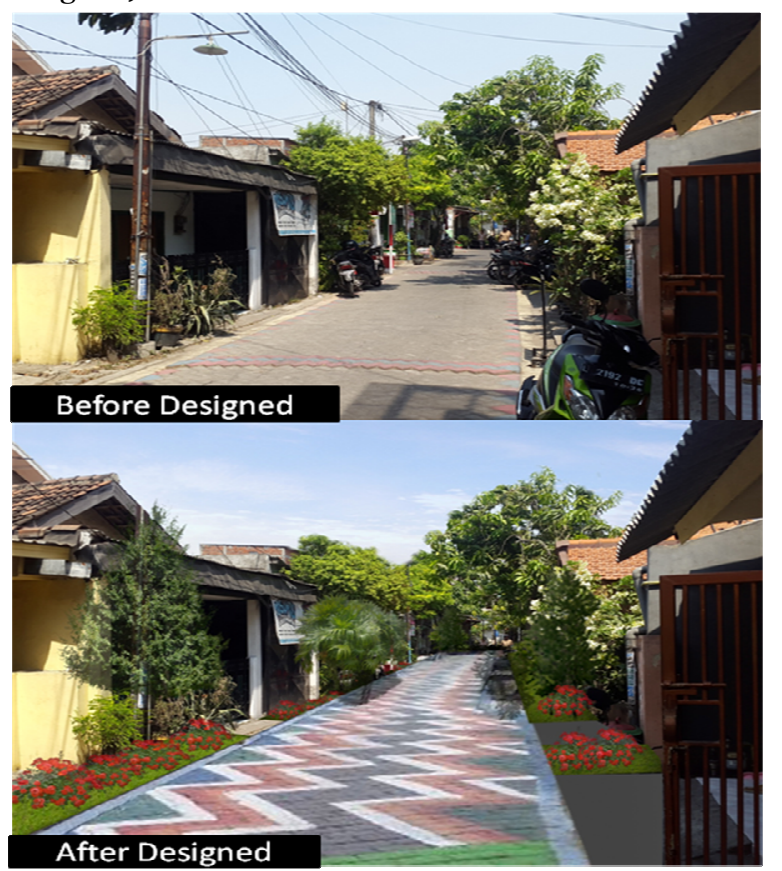

Fig. 7. Street mural (source: Street mural illustration of kampung warni (the colorful kampung) in Madiun).

The concept of this mural is to tell the history of the development of the kampung and to illustrate how various cookies are made (Fig. 6 after designed). Street murals are created along the streets of Kampung 
of Cookies (see Fig. 7). The concept of street mural is focused on full colour, because it is intended to attract attention so that it can be interesting to the visitors.

\subsubsection{Signboard}

The signboard is placed in front of the cookies manufacturer's house.

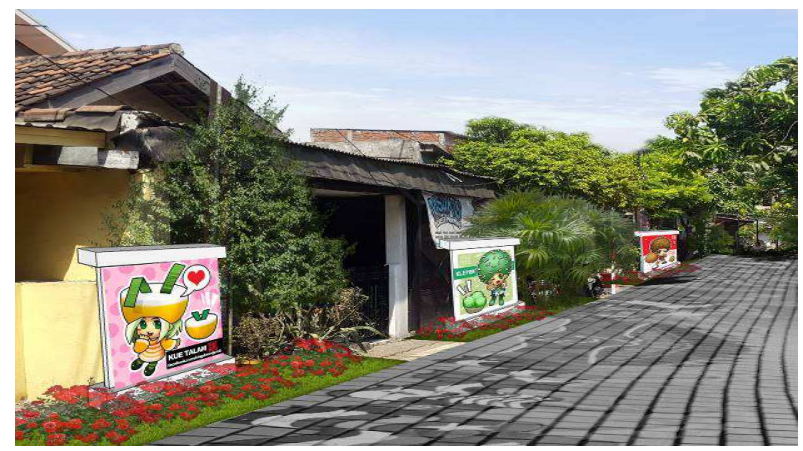

Fig. 8. Signboard proposal (source: illustration byfacebook.com/kingdomofjemil).
Signboard is used as a marker indicating that the house is a cookies production house. In this kampung there is a rule that one person may maximally manage 3 types of cookies. Figure 8 shows the zones of signboard placement based on the location of manufacturer's houses and the proposal of signboards.

\subsubsection{Tour route}

The tour route is planned so that tourism activities are more optimal, do not collide and so that all facilities are passed by. The tour route starts from the east, which is from the Rungkut Asri Utara Street 1. The main entrance is placed in the east because the level of road mobility is lower than the west road. And this minimizes possible road congestion. Tourists enter through the main gate of the kampung, go around the route through the cookies production, subsequently go to the mural area and finally end up in the cookies showroom (Fig. 9).

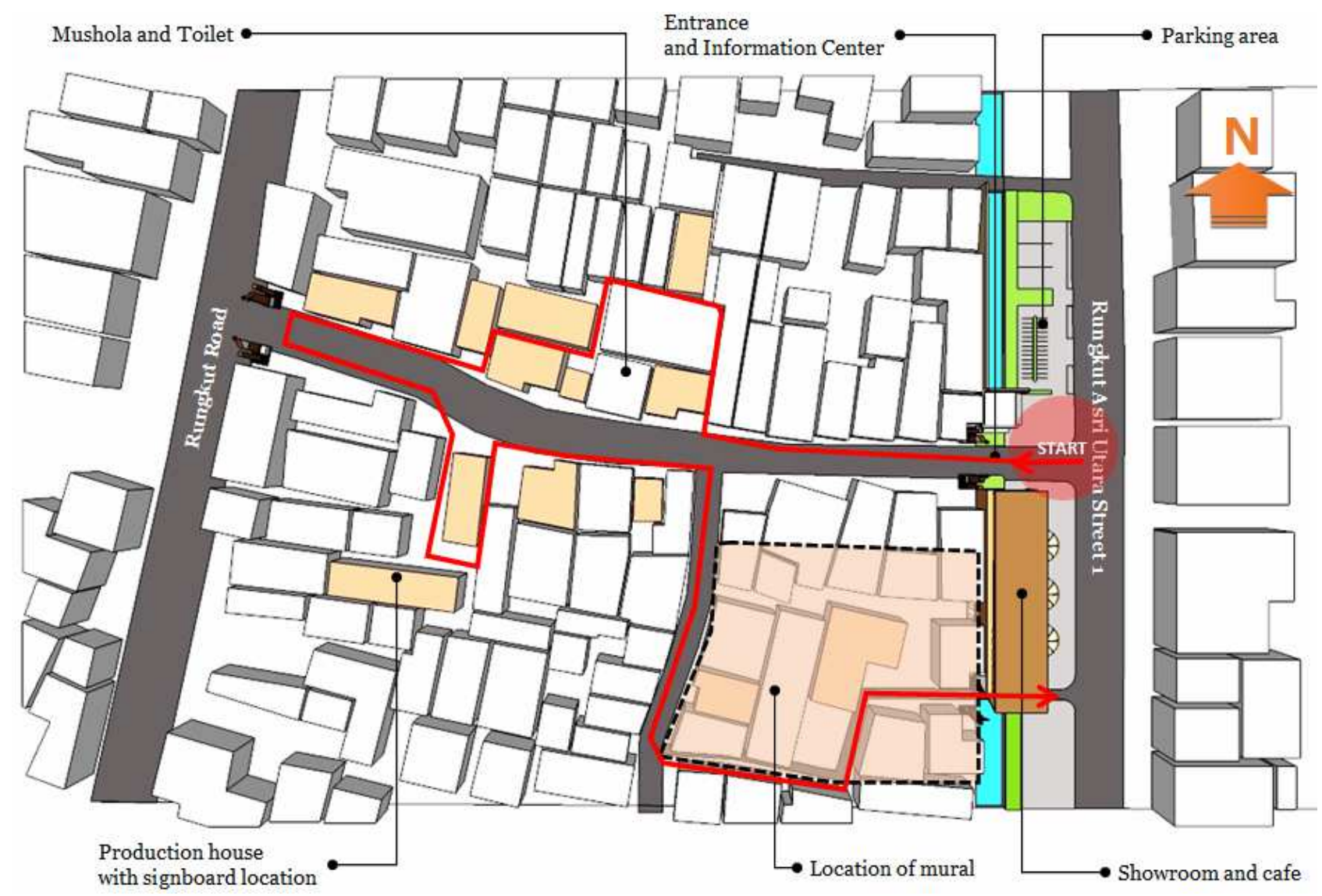

\subsection{Tourist destination}

This kampung is strategic enough to serve as a tourist spot because of its location in the centre of the city and located in the city of Surabaya where the development of tourism and superior kampung is growing rapidly. However, the location of this Kampung of Cookies is adjacent to the Industrial area of SIER (Surabaya Industrial Estate Rungkut) (Fig. 10), and the main access road to the kampung is on a dense traffic path so that it is crossed by large trucks. Alternatively, its development it can be improved by changing the main entrance to the east of the kampung exactly in Rungkut Asri Utara street 1 (see Fig. 4). 


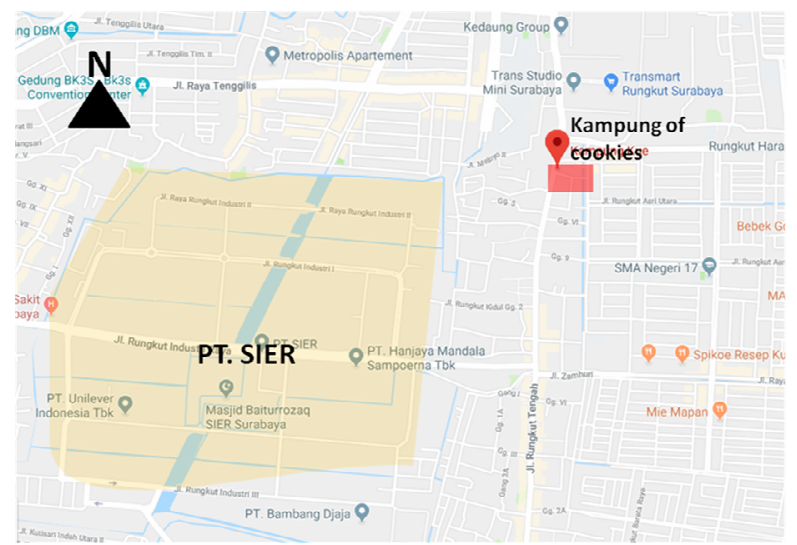

Fig. 10. Location of PT. SIER (source: www.maps.google.com).

In terms of target tourists, this Kampung of Cookies is well known in Surabaya especially by numerous students from universities who come to research up the companies that intend to initiate partnerships with citizens. But on the national scale, this kampung has not yet been acknowledged. During this time, the visitors interested to come here were generally from Surabaya and the surrounding areas. Some visitors as mass media representatives and some from abroad did some researches on this area. In its development, a team would be needed to specifically perform promotions either online or offline so that this Kampung of Cookies could become popular.

In terms of transportation, the access time from Juanda airport to this Kampung of Cookies is of 15 $\mathrm{km}$ or 30 minutes travel. It is quite easy on the highway. From Gubeng rail station, the distance is of $8.7 \mathrm{~km}$ or it can be reached in 20 minutes. From Bungurasih bus terminal, the distance is of $8.7 \mathrm{~km}$ or 20 minutes trip. But there is no mode of transportation that specifically serves the route through the Kampung of Cookies. So, for its development, this research proposes a specific destination to this Kampung of Cookies, namely the Surabaya tourist bus route.

The public facilities located around the kampung are the new market of Rungkut, which is 500m away and can be reached by foot, the modern supermarket Transmart Rungkut within a distance of $650 \mathrm{~m}$, the sub-district office and SDN Kalirungkut $350 \mathrm{~m}$, the Royal hospital within $2.9 \mathrm{~km}$ distance, and the nearest hotel - Fave Hotel Rungkut within a distance of $650 \mathrm{~m}$. The hotel is decent enough for tourist accommodation, but there is no specific accommodation that is provided for tourists who want to visit the Kampung of Cookies. In this case, visitors who want to stay in order to get to know the activities/life in Kampung of Cookies could be then facilitated by residents using their own house rooms for tourists. To be sustainable, the house rooms should be clean and comfortable. This may certainly improve the economy of local citizens. Besides, benefits can also be obtained by tourists considering that they will know first-hand the life and social culture that exist in this local community.

\subsection{Environment}

In the development of tourism, environmental issues must be considered. This is because it is also an interesting component that can be used as tourist attraction (Lailia, 2014). For example, tourist attractions in the kampung of Gundih (one of tourism kampung in Surabaya) are the preservation of the environment such as greening, waste processing, water utilizing, and others. But in the development context of this research, environmental preservation is only focused on the main infrastructures, some of which have been completed such as greening and waste management.

The greening effort (Fig. 11) made by the community consists in planting crops in every household (shrubs, plants and trees.

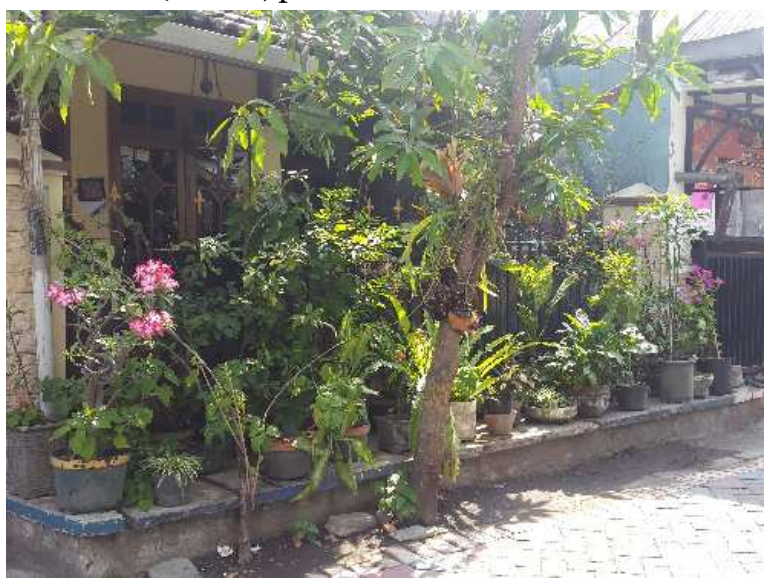

Fig 11. Greening example in Kampung of Cookies.

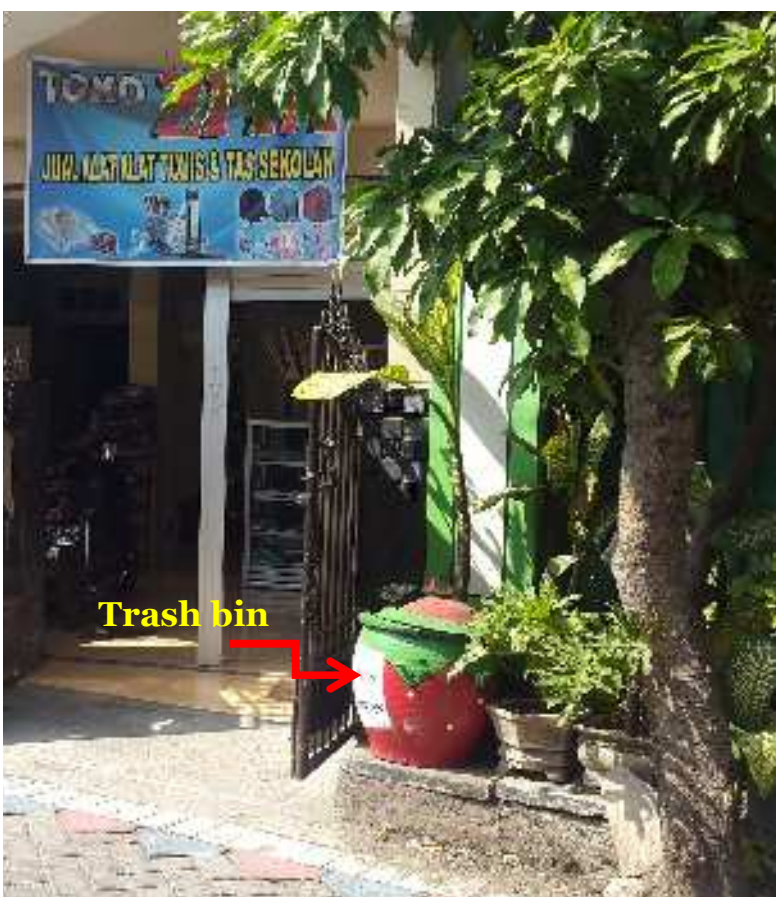

Fig 12. Trash bin in Kampung of Cookies. 
This also supports sustainable development, related to energy efficiency (United Nation, 2016). The energy efficiency that results from greening is to provide natural ventilation in the home, so that people can minimize artificial ventilation. This effort will be very helpful considering the weather in Surabaya is very hot. Kampung of Cookies, which is an industrial centre, produces a lot of waste from the production. In this kampung, residents cannot make efforts to treat waste independently due to limited land. Thus, waste management is accommodated by external actors (waste processing service). This is also intended to maintain the sustainability of tourist kampung, because cookies production space must be sterile from any kind of germs and bacteria caused by garbage. Besides that, it is used to maintain visitor's comfort. Waste management of this kampung consists in placing trash bins in each house and public areas (Fig. 12). Waste collection is done daily.

Some other facilities to be improved to comply with the principles of sustainable development are the following:

Parking area (Fig. 13). When aiming to develop this kampung for tourism, the increase of visitor interest must be considered and anticipated. If the parking is only placed in the alley of the kampung it will be disturb the tourism activity. Alternative parking location is proposed to be placed on the east of the kampung which is located in the green area of the river (see Fig. 4).

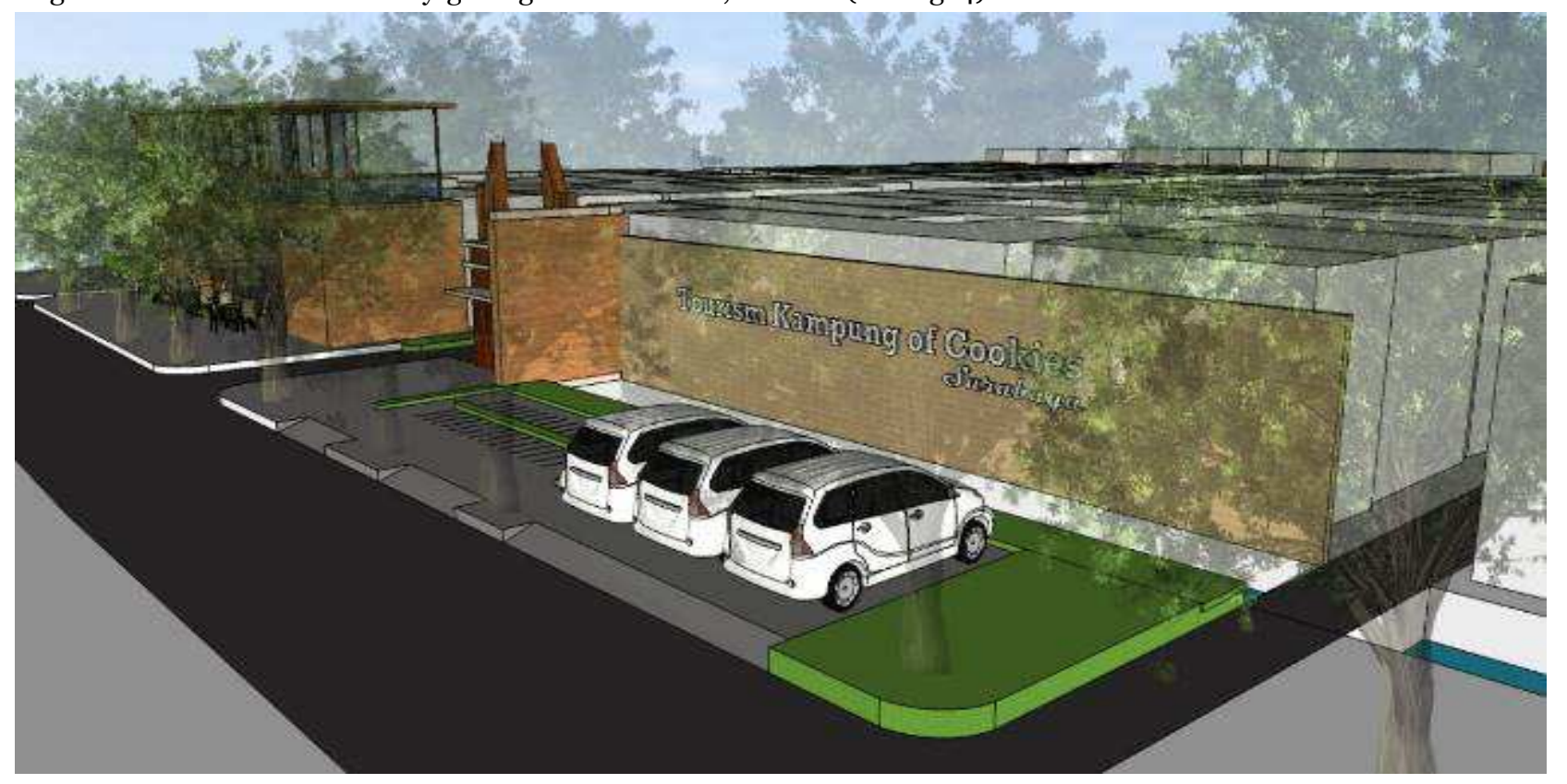

Fig. 13. Parking area proposal.

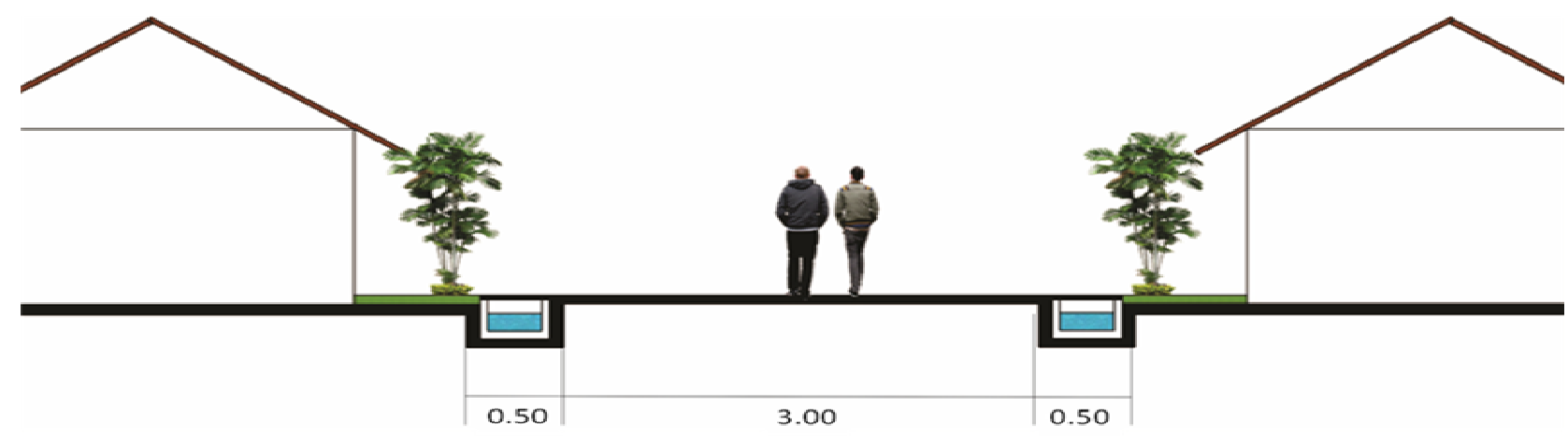

Fig. 14. Drainage proposal.

Lavatory. In this kampung there is still no public toilet. In fact, this is a very urgent facility in the development of a tourist kampung. Alternative toilet placement is proposed to be placed near the mosque, which is in accordance with the intention of locating public facilities in the centre area (see Fig. 4).

Drainage. Flood problems are still an issue in this kampung, because the drainage is inadequate and the river is polluted by garbage. This is a problem that must be resolved because it is not possible for an area to become a tourist destination if the level of cleanliness is still low (Putra, 2002).

The solution for this problem is a closed dranage system (see Fig. 14). This intends to protect drainage from garbage, and the water can flow smoothly. 


\subsection{Economy}

Since inauguration, Kampung of Cookies has recorded very rapid economic growth. Turnover every month can reach up to 20 to 30 million rupiah for each cookie entrepreneur. This income increases, and can even double on the special days like Eid (Muslim celebration) and others. Previously, inhabitants of this kampung benefitted from Corporate Social Responsibility (CSR) funds from Bogasari Ltd., for the development of their cookies business. Such cooperation is very good in supporting the development of tourist kampung, but must be balanced with the involvement of the local community, which is necessary to maintain the sustainability of tourism (Indrianto et al., 2014). The cooperative of this kampung has a savings and loan business unit which is self-help managed. Seeing the success of the cooperative which is the embryo of the capital of cookies entrepreneurs, this cooperative can be used as the financial support for the sustainability of the tourist kampung. To enhance the promotion of the tourist kampung of cookies, through various media, both offline and online actions must be made. An example of offline media is by distributing brochures, pamphlets, billboards, etc., while online media should be done through websites, social media (Instagram, Facebook, etc.), and others. The social media is now being used by almost all tourism business
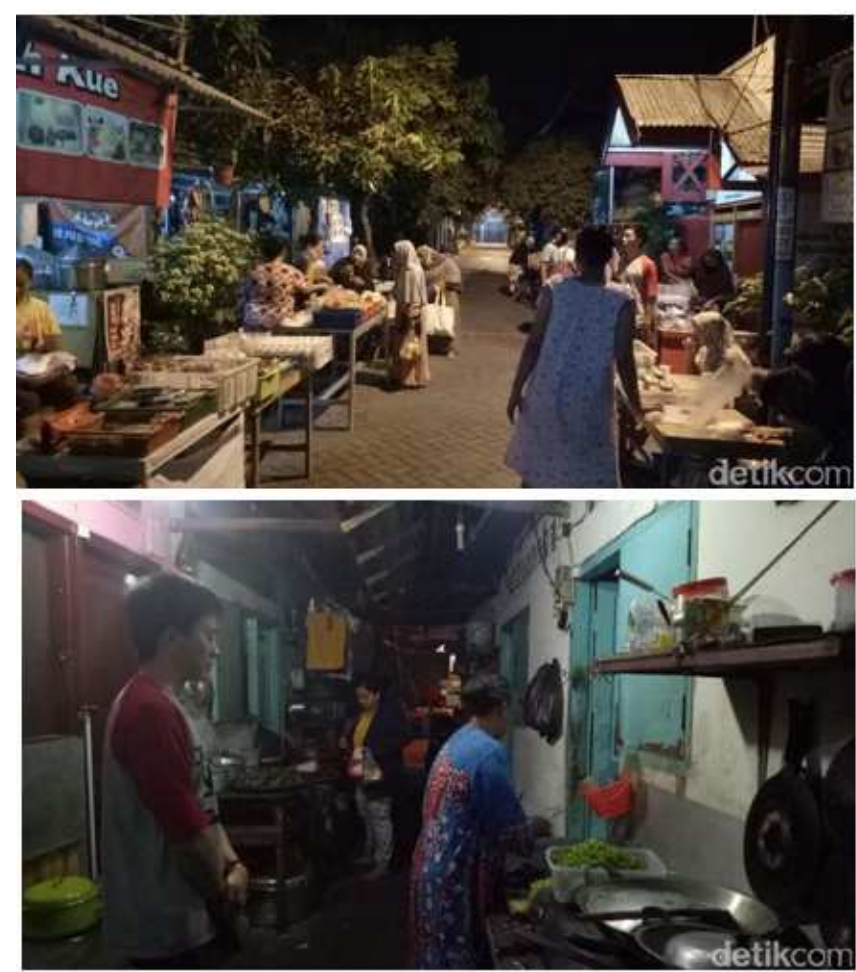

Fig. 15. The purchase and selling activity (source: detik.com).

This is because this kampung is the main distributor of cookies in Surabaya, so cookies making is done in the early day. At noon, the kampung is quiet because people are resting. So this is a special concern when it comes to developing it into a tourist kampung. managers to promote their activities (Luthfiana, 2016).

In addition, branding and cookies packaging to make the products more attractive is needed, so that the target for marketing the cookies can be lifted up to the upper middle-class. Business legality also becomes one of the things to struggle for. Up to now, 10 business units have received business legality and halal (permission certificate in traditional Islamic law).

The locations for marketing these products that have been assisted by the local government are the Municipal Office, Bappenas, Bazar and the Souvenir Centre of Panen Raya. In the future, business units that function legally, have halal certificate and benefit from a good packaging are expected to target the upper middle/higher class. Next, marketing should extend to the larger market, such as centre of souvenirs, malls and other locations.

\subsection{Social and culture}

Behind the famous Kampung of Cookies, many visitors feel disappointed after coming here because they cannot see the activities that represent the Kampung of Cookies. Activities in the Kampung of Cookies take place during the night, until the morning. The community makes the cookies starting at 10.00 P.M. and the purchase and selling activity is done from 03.00 A.M (Fig. 15), until maximum at 06.00 A.M.
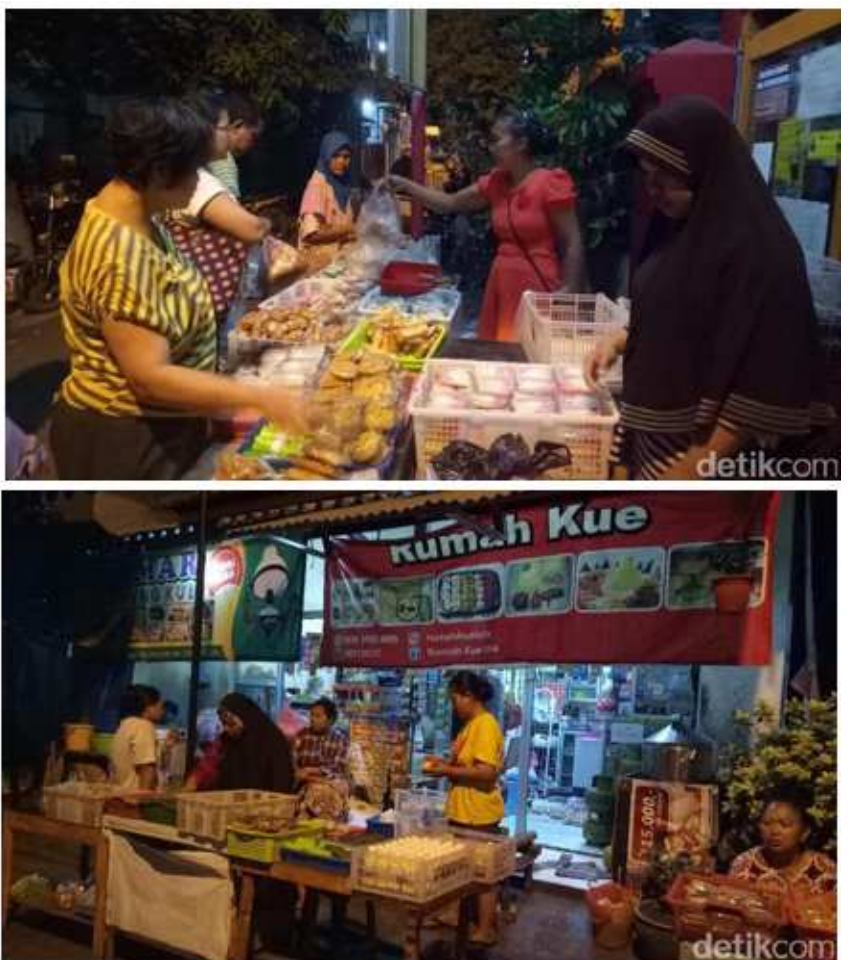

In this case, the effort that can be done is by empowering residents who do not sell cakes to become tourist managers. Of the 200 households in the neighbourhood association number 4 (RT), there are 60 families that produce cookies, so that tourism could be 
organized based on the Neighbourhood scale, and not just considering people who produce cookies.

The development of cookies business in this kampung is self-operated, so that the future tourism would represent community based tourism (CBT). The CBT approach emphasizes that people are more subject to tourism rather than being objects (Ardika, 2004). The main stakeholder in the development of a tourist kampung is the community and community leaders, who are the main determinants in the decision-making process (Purnamasari, 2011). Local community has a high self-belonging towards the settlement environment which is proved with the excellent social conditions, community organizations that running smoothly, and people that have high ideals towards the Kampung of Cookies development. The concept of CBT proved to be very effective in maintaining the sustainability of the tourist kampung (Supriharjo et al., 2015).

The concept of CBT should also be implemented regarding the socio-cultural aspects in order to (a) involve the community in every planning stage; (b) create community pride and a sense of community ownership of tourism; (c) preserve cultural uniqueness and local characteristics, in this case preserving traditional cookies; (d) add value to local culture, such as upgrading traditional cake recipes; (e) offer tourism goods and services responsible for social and environmental livelihoods, in consideration of the advantages and disadvantages of the community; (f) create educational opportunities for local communities such as management training or expertise in managing tourism, accompaniment etc.; and (g) support the role of community institutions, such as cookies-making association (Purnamasari, 2011).

In addition to the above strategies, another aspect to be considered is the empowerment of women (Dianingrum, 2017) in which women are the spearhead in a participatory development (Rinawati, 2004). In this context it is important to note that most of Kampung of Cookies developers are women and most of their activities are done within their neighbourhoods. In this case, the Organization of Family Welfare Education (PKK) can be involved. Moreover, in the category of tourist attractions we could include showrooms and cafés. Showrooms and cafes are suitable since cookies are ready stored, therefore visitors can enjoy them. Consequently, every cookie entrepreneur must make additional cookies to be marketed in showrooms and cafes. In terms of government intervention, the government has been involved in the development of kampongs, namely through the Department of Industry and Commerce City (Disperindag) covering business legality, marketing location, training, liquefied petroleum gas (LPG), social capital and the freedom of HBEs actors. In the development of the next tourist kampung, the involvement of the government in the form of licensing of land use over the river as a tourist facility is needed. Further, tourism development training is also necessary in order to maintain the sustainability of the tourist kampung.

\section{CONCLUSION}

The development concept of the Kampung of Cookies into a tourist kampung is an educational based tourism. Tourist attractions to be presented are in the form of cookie-making demonstrations, cookies festivals, cookies displays, and cartoon cookies photospot. For accommodating these attractions there are several facilities that must be established, including showrooms, cafés, wall and street murals, and signboards. In addition, tourist support facilities that are also needed include toilets, information points, parking lots, and wastewater drainage facilities.

The concept of tourism development management must be the Community Based Tourism (CBT) because this Kampung of Cookies stands with a bottom-up system in which the initiative is started from the community itself. The success of CBT can maintain tourism sustainability because community has the sense of belonging in their residence, so they care about it. The proposal of kampung tourism management is to be organized based on neighbourhood scale (RT). To increase the income of citizens and ensure the sustainability of the kampung, online and offline promotion should be initiated. In addition, good branding and packaging will be able to reach upper middle-class.

This tourist kampung cannot be sustainable if it does not get intervention from the government and participation from the community. In addition, this is also not sustainable tourism if tourist attractions are not continuously developed and if the quality of cookies is not maintained.

\section{ACKNOWLEDGEMENTS}

The authors wish to thank Architecture ITS Department especially Housing and Human Settlement Laboratory for all the support and guidance, so this research could be completed properly.

\section{REFERENCES}

Aditya R. (2015), Pengaruh Media Sosial Instagram Terhadap Minat Fotografi pada Komunitas Fotografi Pekanbaru. JOM FISIP, vol. 2, Retrieved from: https://jom.unri.ac.id/index.php/JOMFSIP/article/vie w/5880/5750. Accessed on November, 9, 2017.

Agoes A. (2015), Tourism Product Development in Kampung Dago Pojok, Bandung. Jurnal Managemen Resort dan Leisure, 12(1). Retrieved from: ejournal.upi.edu/index.php/jurel/article/download/10 49/717. Accessed on October, 4, 2017. 
Ardika I. W. (2004), Pariwisata Bali: Membangun pariwisata budaya dan mengendalikan budaya pariwisata. Pustaka Bali Post: Denpasar.

City Development Planning Board of Surabaya (2015), Regional Regulation of the Surabaya City No. 10 of 2016. Regional Medium Term Development Plan of Surabaya (2016-2021). Retrieved from: https://jdih.surabaya.go.id/pdfdoc/perda_757.pdf Department of Communication and Informatics of Surabaya (2016), Surabaya City Profile 2016. Retrieved from: https://surabaya.go.id/uploads/ attachments/2016/10/13986/profil_surabaya_2016_vf inal_ar_compressed_compress.pdf

Dianingrum Anita (2017), Perkembangan Program Perbaikan Kampung dan Pemberdayaan Masyarakat di Surabaya. Master's thesis (unpublished), Institut Teknologi Sepuluh Nopember. Retrieved from: http://repository.its.ac.id/43667/

Funo S., Yamamoto N., Silas J. (2002), Typology of kampung houses and their transformation process. Journal of Asian Architecture and Building Engineering 1(2), 193200. DOI: https://doi.org/10.3130/jaabe.1.2_193.

Gunn C. A. (1988), Tourism Planning. Second Edition. Taylor \& Francis, New York.

Hidayat D., Setiawati S. D., Ngare F., Oktaviani F., Suhartini T. (2018), Representasi Kampung Seni Dago Sebagai Objek Wisata Kota Bandung. Jurnal Pengabdian Kepada Masyarakat, 1(1), 39-44. Retrieved from: https://ejournal.bsi.ac.id/ejurnal/index.php/jika /article/view/215. Accessed on June 18, 2018.

Indrianto A. L., Satrya D. G., Wicaksi A. (2014), CSR di Kampung Wisata Jambangan. Jurnal Ilmiah Pariwisata, 19(2). Retrieved from: http:// jurnal pariwisata.stptrisakti.ac.id/index.php/JIP/article/view /18. Accessed on June 18, 2018.

Inskeep Ed. (1991), Tourism Planning An Integrated and Sustainable Development Approach. Van Nostrand Reinhold, New York.

Isabella M. (2010), Kampung Wisata Ledok Macanan di Yogyakarta. Thesis. Department of Architecture. UAJY. Retrieved from: e-journal.uajy.ac.id/2412/. Accessed on September, 28, 2017.

Kurniawati R. (2013), Modul pariwisata berkelanjutan. Retrieved from: https://rinakurniawati. files.wordpress.com/2013/o1/modulpariwisataberkelan jutan.pdf. 2013. Accessed on October, 4, 2017.

Lailia A. N. (2014), Gerakan Masyarakat dalam Pelestarian lingkungan hidup. Jurnal Politik Muda, 3(3), 283-302. Retrieved from: http://journal.unair. ac.id/filerPDF/jpm9230107744full.pdf. Accessed on June 18, 2018.

Luthfiana M. P. (2016), Pengaruh Kemenarikan Pesan Foto Di Media Sosial Terhadap Keputusan Berkunjung Wisatawan Di Farmhouse Susu Lembang, Kabupaten Bandung Barat. Thesis, Indonesia University of Education. Retrieved from: http://repository.upi.edu/id/eprint/24488. Accessed on December, 15, 2017

Mill R. C., Morrison A. M. (1985), The Tourism System. Prentice Hall, Inc., New Jersey.

Ministry of Tourism (2009), Laws of The Republic Indonesia No. 10 of 2009 The Tourism Act. The National Tourism Development Master Plan 20102025. Retrieved from: http://www.kemenpar. go.id/userfiles/file/4636_1364-UUTentangKepariwis ataannet1.pdf

Mulyadi E. (2014), Kamus Fotografi. Elex Media Koputindo, Jakarta.

National Development Planning Agency (2014). National Middle Term Development Plan 2015-2019. Retrieved from: http://www.social-protection.org/ gimi/gess/RessourcePDF.action?ressource.

ressourceId $=50077$

Nuryanti W. (1993), Concept, perspective and challenges. International conference report on tourism. Gadjah Mada University Press, Yogyakarta.

Purnamasari A. M. (2011), Pengembangan masyarakat untuk pariwisata di kampung wisata Toddabojo Provinsi Sulawesi Selatan. Jurnal Perencanaan Wilayah dan Kota, 22(1).

Putra G. G. A. (2002), Perilaku masyarakat dalam pemeliharaan kebersihan lingkungan permukiman untuk menunjang program sapta pesona pariwisata. Thesis. Universitas Diponegoro Semarang. Retrieved from:http://eprints.undip.ac.id/11610/1/2002MIL1385 .pdf. Accessed on December, 14, 2017.

Rinawati Rini (2004), Partisipasi wanita dalam pembangunan. Jurnal sosial dan pembangunan. 20(3), 387-405. Retrieved from: https://media.neliti.com /media/publications/157253-ID-partisipasi-wanita dalam-pembangunan.pdf. Accessed on June, 19, 2018.

Setyaningsih W., Iswati T. Y., Yuliani S. (2014), The Application of the Concept of Eco Green-Tourism. In Developing the Tourist Village through the Low Impact Development. Journal of Architecture \& Environment, 13(1), 93-110. DOI: http://dx.doi.org/10. 12962/j2355262x.v13i1.

Silas J., Setiawan W., Ernawati R., Okitasari M. (2013), The Kampungs of Surabaya. Entering the 21th century. Planning and revitalization of Surabaya kampungs. City Development Planning Board. Surabaya.

Supriharjo R. D., Rahmawati D., Santoso E.B., Setiawan R. D., Pradinie K. (2015), Factors influencing community-based heritage sustainability in Kampung Kemasan, Gresik. Procedia - Social and Behavioral Sciences, vol. 227, pp. 498-502. DOI: https://doi.org/10.1016/j.sbspro.2016.06.106.

Suwena W. (2010), Pengetahuan Dasar Ilmu Pariwisata. Udayana University Press, Denpasar.

United Nation World Tourism Organization (UNWTO) (n.d.), Measuring Sustainable Tourism. Retrieved from: http://cf.cdn.unwto.org/sites/all/files/ 
docpdf/folderfactsheetweb.pdf. Accessed on October 4, 2017.

United Nations (2016), New Urban Agenda. Retrieved from: http://habitat3.org/wp-content/ uploads/NUA-English.pdf

Yoeti O. A. (1996), Pengantar Ilmu Pariwisata. Angkasa: Bandung.
Zakaria F., Supriharjo R. (2014), Konsep Pengembangan Kawasan Desa Wisata di Desa Bandungan Kecamatan Pakong Kabupaten Pamekasan. Jurnal Teknik Pomits, 3(2), 2337-3520. Retrieved from: http://ejurnal.its.ac.id/index.php/ teknik/article/view /7292. Accessed on November 9, 2017. 